\title{
Microfiltration of Butter Serum Upon Casein Micelle Destabilization
}

\author{
R. Rombaut, ${ }^{1}$ V. Dejonckheere, and K. Dewettinck \\ Laboratory of Food Technology and Engineering, Department of Food Safety and Food Quality (BW07), \\ Faculty of Bioscience Engineering, Ghent University, Belgium
}

\section{ABSTRACT}

The gross composition of butter serum, the aqueous phase of butter, is comparable to that of buttermilk, except that it has a higher content of material derived from the milk fat globule membrane (MFGM). As such, butter serum is a good source for further purification of MFGM material. The purified fraction could be of interest for its emulsifying and nutritional properties. The effect of sodium citrate and ethanol on the dissociation of butter serum casein micelles, and their effect on casein retention upon tangential microfiltration were investigated. Optimal conditions of casein micelle dissociation were assessed by using an experimental design (response surface full central composite orthogonal design) with temperature and ethanol or sodium citrate concentration as design variables and the Hunter $\mathrm{L}^{*}$ value as response variable. For both dissociating agents, a highly significant reduced quadratic model was fit to the data. Microfiltration tests were performed on pure butter serum, and on butter serum in the presence of sodium citrate, under optimal dissociation conditions $\left(50^{\circ} \mathrm{C}, 80 \mathrm{mM}\right)$. A cellulose acetate membrane with a pore size of $0.15 \mu \mathrm{m}$ was used. From the filtration curves and fouling coefficients it was clear that the addition of sodium citrate improved the permeation flux, and minimized fouling. All fractions were analyzed for dry matter, protein, lactose, lipid, and polar lipid contents. The protein fraction was further characterized by sodium dodecyl sulfate-PAGE. It was shown that sodium citrate greatly enhanced casein transmission through the membrane, but at the expense of substantial losses of polar lipids.

Key words: butter serum, milk fat globule membrane, polar lipid, casein destabilization

\section{INTRODUCTION}

The milk fat globule membrane (MFGM) is a true biological membrane that surrounds the milk fat droplets. It prevents the globules from coalescence, stabi-

Received November 15, 2005.

Accepted December 20, 2005.

${ }^{1}$ Corresponding author: roeland.rombaut@UGent.be lizes them in the milk serum, and protects them from enzymatic attack by lipases (Danthine et al., 2000; Evers, 2004). The membrane comprises approximately $60 \%$ proteins and $40 \%$ lipids (Fox and McSweeney, 1998; Keenan et al., 1999). Numerous proteins are associated with the MFGM, of which xanthin oxidase, periodic acid/schiff 6/7, adipophilin, and butyrophilin are the most abundant (Mather, 2000). The lipids of the MFGM are mainly cholesterol and phospho- and sphingolipids, in varying proportions. The major phospholipids are phosphatidylethanolamine, phosphatidylcholine, phosphatidylserine, and phosphatidylinositol. The major sphingolipids are glucosylceramide, lactosylceramide, and sphingomyelin (Deeth, 1997; Keenan et al., 1999). The sum of phospho- and sphingolipids comprise the polar lipids (PL). Mechanical treatments such as heating (Kim and Jimenez-Flores, 1995), homogenization (Cano-Ruiz and Richter, 1997), aeration, and agitation (Evers, 2004) induce MFGM release from the fat globule into the corresponding serum phase. Upon phase inversion of the fat globule, such as occurs in churning, membrane material is released in the serum fraction (i.e., buttermilk and butter serum).

Because of its origin and amphiphilic nature, MFGM isolates were found to show good emulsifying properties (Kanno, 1989; Kanno et al., 1991; Corredig and Dalgleish, 1997). Therefore, MFGM isolates could be used as emulsifiers or fat replacers in a range of products (e.g., mayonnaise, margarine, recombined butter, instant milk powder, cosmetics, and pharmaceuticals; Schneider, 2001). In addition to their technological properties, evidence is growing that several MFGM components could be nutritionally advantageous. The capability of dietary sphingolipids to reduce the uptake of cholesterol (Eckhardt et al., 2002; Noh and Koo, 2004), protect against bacterial infections in the gut (Vesper et al., 1999; Pfeuffer and Schrezenmeir, 2001), as well as their inhibitory effect on colon cancer (Schmelz, 2004; Duan, 2005) have been intensively studied. Bioactive peptides derived from MFGM proteins upon digestion have also gained attention, as they can positively interfere in breast and colon cancer, multiple sclerosis, and hypercholesterolemia (Spitsberg, 2005). 
Milk fat globule membrane fragments are often purified from buttermilk, although other dairy fractions such as butter serum could be of more interest. Butter serum, the aqueous phase of butter, is a by-product of anhydrous milk fat production. In this process, butter is melted (or a 75\% cream can be homogenized, forcing phase inversion) and centrifuged, resulting in pure butterfat and butter serum. The composition of butter serum is roughly comparable to that of buttermilk, except for the fat content, which is much higher (up to 4.5\%; McPherson and Kitchen, 1981). The phospho- and sphingolipid contents (and indirectly, MFGM fragments) of butter serum are much higher than those of buttermilk. For buttermilk, concentrations between 71 and $160 \mathrm{mg} / 100 \mathrm{~g}$ are reported, whereas for butter serum, values of 660 and $1,250 \mathrm{mg} / 100 \mathrm{~g}$ are published, making the latter more attractive for MFGM purification (McPherson and Kitchen, 1981; Christie et al., 1987; Sachdeva and Buchheim, 1997; Rombaut et al., 2005; Rombaut et al., 2006).

The separation of MFGM material from other dairy constituents can be achieved by tangential microfiltration (MF). This technique has been successfully used for the separation and fractionation of milk fat globules (Goudédranche et al., 2000), cold pasteurization of consumption milks (Trouve et al., 1991), and enrichment of caseins before cheese making (Ardisson-Korat and Rizvi, 2004). However, difficulties arise when using buttermilk as a source for MFGM purification. Milk fat globule membrane particles and buttermilk caseins are comparable in size, which makes separation impossible with $\mathrm{MF}$ alone, even after optimization of temperature and pore size (Morin et al., 2004). Sachdeva and Buchheim (1997) circumvented this problem by inducing acid or rennet coagulation of the caseins before $\mathrm{MF}$, accepting a loss of $20 \%$ of polar lipids in the curd. As an alternative, $\mathrm{MF}$ of buttermilk or butter serum in the presence of an agent that dissociates casein micelles into smaller submicelles (thus reducing its retention upon filtration) could be promising. Agents such as urea (McGann and Fox, 1974), ethanol (Zadow, 1993; O'Connell et al., 2001a), and citrate (Udabage et al., 2000) have been shown to induce a reversible reduction in micelle size. Corredig et al. (2003) successfully concentrated MFGM material by MF of buttermilk in the presence of sodium citrate. However, no actual PL concentrations of the MF retentate were given.

Butter serum has not been fully characterized with regard to PL content, MFGM proteins, and casein dissociation, nor has it been used as a source for MFGM purification by MF. In this study, we present data on the composition of butter serum, on the behavior of butter serum casein micelles as a function of temperature and ethanol or sodium citrate concentration, and on the direct MF of butter serum with and without the presence of sodium citrate.

\section{MATERIALS AND METHODS}

\section{Materials}

Butter serum powder was obtained from Solarec (Recogne, Belgium) and reconstituted by adding $11 \mathrm{~g}$ of powder to $100 \mathrm{~g}$ of deionized water at $40^{\circ} \mathrm{C}$ under agitation. It was allowed to stand overnight at $4^{\circ} \mathrm{C}$ to ensure full hydration. Chloroform, methanol, diethyl ether, and petroleum ether used for lipid and PL extraction were of $>99 \%$ purity. Chloroform, methanol, trimethylamine, and formic acid used as the mobile phase were of HPLC grade. Ethanol and sodium citrate $\left(\mathrm{Na}_{3}\right.$ $\mathrm{C}_{6} \mathrm{H}_{5} \mathrm{O}_{7} \cdot 2 \mathrm{H}_{2} \mathrm{O}$ ) for casein micelle dissociation were respectively of $>98 \%$ and $>99 \%$ purity. A milk PL standard was supplied by Spectral Services (Köln, Germany).

\section{Analyses}

DM, Protein, Lipids, Reducing Sugars, and PL. Dry matter analyses were performed by gravimetric difference after heating (IDF, 1987a). Lipid content was obtained gravimetrically after evaporation of the extraction solvent (diethyl and petroleum ether) using the Röse-Gottlieb extraction method (IDF, 1987b). It is possible that not all PL are extracted by this method; therefore, the term "lipids," rather than total lipids, is used. The protein content was obtained using the Kjeldahl nitrogen determination method (IDF, 1993), using 6.38 as the protein conversion factor. Sugar content was determined by measuring the amount of reducing sugars (Luff Schoorl method; Acker, 1967). Polar lipid extraction with chloroform/methanol and analysis by HPLC (Thermo Finnigan Surveyor, Thermo Corp., Brussels, Belgium) coupled to an evaporative light scattering detector (ELSD 2000, Alltech Inc., Lokeren, Belgium) were performed as described elsewhere (Rombaut et al., 2005). All analyses were performed in duplicate.

Protein Profiling by SDS-PAGE. All reagents and precast gels were purchased from Invitrogen (Merelbeke, Belgium). The samples were diluted 10 -fold in ultrapure water, and washed with an equal volume of $2: 1$ ( $\mathrm{vol} / \mathrm{vol}$ ) chloroform:methanol solution to remove PL contaminants. After washing, the lower layer was discarded. Samples were prepared following the manufacturer's protocol. Two hundred fifty microliters of $\mathrm{Nu}-$ PAGE LDS sample buffer (Invitrogen, Merelbeke, Belgium) and $100 \mu \mathrm{L}$ of NuPAGE reducing agent were added to $650 \mu \mathrm{L}$ of diluted and defatted sample. The samples were vortexed and heated to $70^{\circ} \mathrm{C}$ for $10 \mathrm{~min}$ 
in a hot water bath. Then, $10 \mu \mathrm{L}$ of each sample was loaded onto a NuPAGE bis-tris $4-12 \%$ polyacrylamide gel $(10 \times 10 \times 0.15 \mathrm{~cm}) ; 3$-N-morpholinopropanesulfonic acid (MOPS) buffer was used as the running buffer. Constant voltage separation was performed in $55 \mathrm{~min}$ at $200 \mathrm{~V}$ and an initial current of $125 \mathrm{~mA} / \mathrm{gel}$. After separation, the gel was washed 3 times with deionized water and stained for 60 min with Coomassie Blue stain (Invitrogen). The gel was destained for $60 \mathrm{~min}$ in deionized water and further overnight in $120 \mathrm{~mL}$ of a $3.3 \%$ $\mathrm{NaCl}$ deionized water solution. The latter was done to increase staining intensity. Scanning of the wet gel was done with a high-resolution transmission scanner (UMAX Powerlook III, Taiwan). Gels were analyzed with the Imagemaster Totallab software (Amersham Biosciences, Roosendaal, The Netherlands).

The MFGM protein standard was purified from fresh raw milk, which was obtained from a local farmer. Ten liters of milk was decreamed at $42^{\circ} \mathrm{C}$ with a small continuous separator (Westfalia Separator, Oelde, Germany) at 12,000 rev/min and washed 3 times with $9 \mathrm{~L}$ of a $1.5 \mathrm{~g} / \mathrm{L}$ solution of $\mathrm{KCl}$. The washed cream was churned with a household beater for $10 \mathrm{~min}$. The obtained butter was melted at $60^{\circ} \mathrm{C}$ and an equal quantity of distilled water was added. The resulting slurry was centrifuged in a batch lab centrifuge (Martin Christ Osterode, Harz, Germany) at 2,400 $\times g$ for $5 \mathrm{~min}$ at $60^{\circ} \mathrm{C}$, and the butter serum was collected. Butter serum and buttermilk were pooled and freeze dried. Removal of residual lipids was done by washing the powder with chloroform. The mixture was filtered on a paper filter and allowed to dry. The purified MFGM protein powder was stored at $-32^{\circ} \mathrm{C}$.

Casein Micelle Dissociation. The Hunter color L* parameter (lightness) was taken as a indicator of casein micelle dissociation (Zadow, 1993; O'Connell et al., 2001a). Sodium citrate was added to the butter serum solution in a capped test tube, vortexed for $30 \mathrm{~s}$, and heated for $10 \mathrm{~min}$ in a hot water bath while shaking regularly. Ethanol/deionized water solutions of different ratios were added to the butter serum in a 1:1 ratio in a capped test tube, vortexed for $30 \mathrm{~s}$, and heated for $10 \mathrm{~min}$ in a hot water bath while shaking regularly. The Hunter $L^{*}$ values of the solutions were measured in 20-mL plastic cuvettes, with a Minolta CM-2500-d portable colorimeter (Konica Minolta, Kontich, Belgium) immediately after heating.

\section{Processing}

Tangential Microfiltration of Butter Serum. The MF unit consisted of an Optisep 200 flatbed tangential filtration module (NCSRT, Inc., Cary, NC) equipped with a cellulose acetate membrane (Schleicher and
Schuell, Gent, Belgium) with a pore diameter of 0.15 $\mu \mathrm{m}$. The process was driven by an Almatec diaphragm pump connected to a pulse dampener (Kamp-Lintfort, Germany). The transmembrane pressure (TMP) was kept constant at 1 bar. The feed flow was $500 \mathrm{~L} / \mathrm{h}$, which resulted in a product velocity over the membrane of $2.14 \mathrm{~m} / \mathrm{s}$. For each filtration process, a new membrane of the same batch was used to ensure that observed differences in filtration behavior were not caused by incomplete membrane cleaning. Before filtration, the membrane was flushed with $10 \mathrm{~L}$ of deionized water. Then, $4.5 \mathrm{~L}$ of butter serum, with and without addition of $80 \mathrm{~m} M$ sodium citrate, was filtered at $50^{\circ} \mathrm{C}$ until 3.4 $\mathrm{L}$ of permeate was obtained. This corresponded with a volume concentration ratio of 4.09. After filtration, the membrane was flushed with $10 \mathrm{~L}$ of water. Samples of original butter serum, retentate, and permeate were stored at $-20^{\circ} \mathrm{C}$ before analysis. The retention coefficient $(\mathrm{RC}, \%)$ was calculated using the equation $\mathrm{RC}(\%)=$ $\left[\left(1-\left(\mathrm{C}_{\mathrm{p}} / \mathrm{C}_{\mathrm{r}}\right)\right] \times 100\right.$, where $\mathrm{C}_{\mathrm{p}}$ and $\mathrm{C}_{\mathrm{r}}$ are the concentration of a component in the permeate and retentate, respectively.

Fouling Coefficient. A fouling coefficient (FC) was defined by Rao (2002) as FC $=1-\left(\mathrm{J}_{\text {fouled }} / \mathrm{J}\right)$, where $\mathrm{J}$ is the permeate water flux of the membrane before filtration, and $\mathrm{J}_{\text {fouled }}$ is the permeate water flux after filtration, when the membrane is fouled. The determination approach was however slightly altered. For pure water, the permeate flux can be written as $\mathrm{J}=\mathrm{TMP} /\left(\mu_{\mathrm{w}} \times \mathrm{R}\right)$, where $J$ is the permeate water flux, $R$ is the hydraulic resistance, TMP is the transmembrane pressure, and $\mu_{\mathrm{w}}$ is the dynamic viscosity of water (Cheryan, 1998). The water flux after rinsing, but before filtration, was measured at a transmembrane pressure of 0.04, 0.06, 0.08 , and 0.1 $\mathrm{MPa}$. By linear regression, these data were fit to $\mathrm{J}=\mathrm{a} \times \mathrm{TMP}$, where "a" is the slope of the curve. After filtration and rinsing, the water flux of the fouled membrane was determined by the same procedure and fitted to $J_{\text {fouled }}=a_{\text {fouled }} \times$ TMP. The FC was calculated as $\mathrm{FC}=1-\left(\mathrm{a}_{\text {fouled }} / \mathrm{a}\right)$.

\section{Statistics and Experimental Design}

Graphics were generated with Sigmaplot 6.0 (SPSS, Inc., Chicago, IL). Statistics and experimental design were performed with SPSS 12.0 (SPSS, Inc.) and Design Expert 5.0 (StatEase, Inc., Minneapolis, MN).

\section{RESULTS AND DISCUSSION}

\section{Casein Micelle Dissociation}

The influence of temperature and citrate or ethanol concentration on casein micelle dissociation was determined by means of an experimental design (response 
Table 1. Statistical parameters of the reduced quadratic models fitted to the experimental data of citrate and ethanol addition

\begin{tabular}{lcc}
\hline ANOVA terms & $\begin{array}{c}\text { Citrate } \\
\text { addition }\end{array}$ & $\begin{array}{c}\text { Ethanol } \\
\text { addition }\end{array}$ \\
\hline Sum of squares & & \\
Model & 361.17 & 595.77 \\
Residual & 15.36 & 23.41 \\
Lack of fit & 7.29 & 11.91 \\
Pure error & 8.08 & 11.50 \\
Corrected total & 376.53 & 619.18 \\
$\quad$ Predicted residual & 30.45 & 88.01 \\
Significance $(P$-value) & & \\
Model & $<0.0001$ & 0.0001 \\
Lack of fit & 0.64 & 0.49 \\
Correlation coefficients & & \\
$\quad \mathrm{R}^{2}$ & 0.96 & 0.96 \\
Predicted $\mathrm{R}^{2}$ & 0.92 & \\
\hline
\end{tabular}

surface full central composite orthogonal design; Table 1). The $L^{*}$ value was taken as a parameter for casein micelle dissociation. Design limits for citrate dissociation were 30 to $70^{\circ} \mathrm{C}$ at citrate concentrations of 20 to $80 \mathrm{~m} M$. Design limits for ethanol dissociation were 40 to $70^{\circ} \mathrm{C}$ at ethanol concentrations of 30 to $80 \%$ (vol $/ \mathrm{vol}$ ). The latter concentration is that of ethanol in the water solution, which is mixed in equal parts with the butter serum. This setup was applied to take into account the dilution effect. Thirteen design points were defined, of which 4 were factorial points, 4 were axial points, and 5 were center points. The latter points determined the pure experimental error. For both experiments, a reduced quadratic model was fit to the data. A stepwise addition algorithm eliminated nonsignificant model coefficients. In Table 1, the ANOVA sum of squares, fitted regression coefficients, and $t$-tests are given for the reduced quadratic model of both experiments. The mentioned predicted residual sum of squares was calculated by recalculating the model coefficients using the data points minus one. This new model was then used to estimate the value for the nonincluded point. This was done for each point, and the difference between each predicted and actual value was squared and summed. As such, it is a measure of how well the model fits each point in the design.

The 2 models, for ethanol and citrate addition, were found to be highly significant. Lack of fit tests, where the pure error is compared with the rest of the residual error (= lack of fit error) were found to be insignificant, which means that the model can be adequately used as a predictor of the $L^{*}$ value within the limits of the experimental design. No significant outliers were observed. The correlation coefficient and predicted correlation coefficient were sufficiently high. The predicted $\mathrm{R}^{2}$ value is based on the predicted residual sum of squares. It gives information about how well the model fits each point in the design, and if the model is prone to small variations of one of the data points. The value should be close to 1 , which is the case for both models. Of all of these parameters, it can be concluded that both models are adequate to predict the $\mathrm{L}^{*}$ value upon citrate and ethanol addition. In Table 2 , the significance of each model coefficient and the final equation terms of the model are given. For both experiments, the $\mathrm{L}^{*}$ value was highly dependent on the concentration. The effect of temperature was highly significant in the case of ethanol addition, but less so for citrate addition. A significant interaction term, which points out that the effect of the concentration on the $\mathrm{L}^{*}$ value is influenced by the temperature (and vice versa), was only observed for ethanol addition. By using the equation terms, the $\mathrm{L}^{*}$ value can be predicted for temperature and concentration combinations within the design boundaries.

In Figure 1, the contour plot of the $L^{*}$ value of butter serum is shown as a function of the temperature and citrate addition. The original $\mathrm{L}^{*}$ value of the butter serum, at $20^{\circ} \mathrm{C}$ and without addition of citrate, was 77.4. As can be seen from the figure, there is a gradual decrease of the $\mathrm{L}^{*}$ value upon citrate addition. The effect of temperature is moderate, being almost negligible at high citrate concentrations. At low citrate concentrations, the $\mathrm{L}^{*}$ value decreases with decreasing temperature. This can be explained by the disruption mechanism of citrate. Citrate is a Ca-binding agent, which dissociates casein micelles by sequestration of colloidal calcium phosphate (Udabage et al., 2000; Huppertz et al., 2004). At higher temperatures, less binding of $\mathrm{Ca}$ occurs, which results in less casein micelle disruption and a higher $\mathrm{L}^{*}$ value. At higher citrate concentrations, the temperature influence is less pronounced, because enough $\mathrm{Ca}$ remains complexed. The lowest $\mathrm{L}^{*}$ value was found to be $57.0 \pm 1.7$ at $30^{\circ} \mathrm{C}$ and at a citrate concentration of $80 \mathrm{mM}$. These results correspond very well with the findings of Huppertz et al. (2004). They reported a steady decrease of the $\mathrm{L}^{*}$ value of raw skimmed milk at $20^{\circ} \mathrm{C}$ upon citrate addition, with a minimum $\mathrm{L}^{*}$ value at $75 \mathrm{~m} M$.

In Figure 2, the contour plot of the $\mathrm{L}^{*}$ value of butter serum is given as a function of the temperature and ethanol concentration. The original $\mathrm{L}^{*}$ value of the $1: 1$ butter serum:water solution was found to be 74.7 at $20^{\circ} \mathrm{C}$. At low temperatures, the $\mathrm{L}^{*}$ value remains almost constant up to $58 \%$ of ethanol, but then decreases quickly upon further ethanol addition. At higher temperatures, the decrease of the $\mathrm{L}^{*}$ value starts at $30 \%$ ethanol, and drops rapidly at higher ethanol concentrations. A minimum $\mathrm{L}^{*}$ value of $51.3 \pm 2.3$ was found at $69.9^{\circ} \mathrm{C}$ and at an ethanol concentration of $79.9 \%$ (vol/ vol). Similar results were obtained by Zadow (1993) and O'Connell et al. (2001a) using skim milk. They both observed an alcohol-dependent, temperature-induced 
Table 2. Significance of reduced quadratic model coefficients and final equation terms for predicting the $\mathrm{L}^{*}$ value within the design limits

\begin{tabular}{lccccc}
\hline & \multicolumn{2}{c}{ Significance $(P$-value $)$} & & \multicolumn{2}{c}{ Final equation terms } \\
\cline { 2 - 3 } Model coefficient & Citrate & Ethanol & & Citrate & Ethanol \\
\hline Intercept & & & & 67.27 & 49.49 \\
Temperature & 0.0183 & 0.0016 & & 0.20 & 0.25 \\
Concentration & $<0.0001$ & $<0.0001$ & & -0.13 & 1.08 \\
Temperature $\times$ concentration & 0.0551 & 0.0057 & & $-2.40 \times 10^{-3}$ & $-8.54 \times 10^{-3}$ \\
Temperature $^{2}$ & $\mathrm{NS}^{1}$ & $\mathrm{NS}$ & & 0 & 0 \\
Concentration $^{2}$ & $\mathrm{NS}$ & 0.0057 & & 0 & $-8.49 \times 10^{-3}$ \\
\hline
\end{tabular}

${ }^{1}$ Nonsignificant terms $(P>0.05)$ are denoted as NS.

dissociation of casein micelles. $L^{*}$ values reached a minimum at $60 \%$ ethanol and $70^{\circ} \mathrm{C}$. The mechanism of casein dissociation upon ethanol addition is rather com- plex. The cohesive interactions between casein molecules on heating in the presence of ethanol are decreased, most likely by an increase in protein hydrophil-

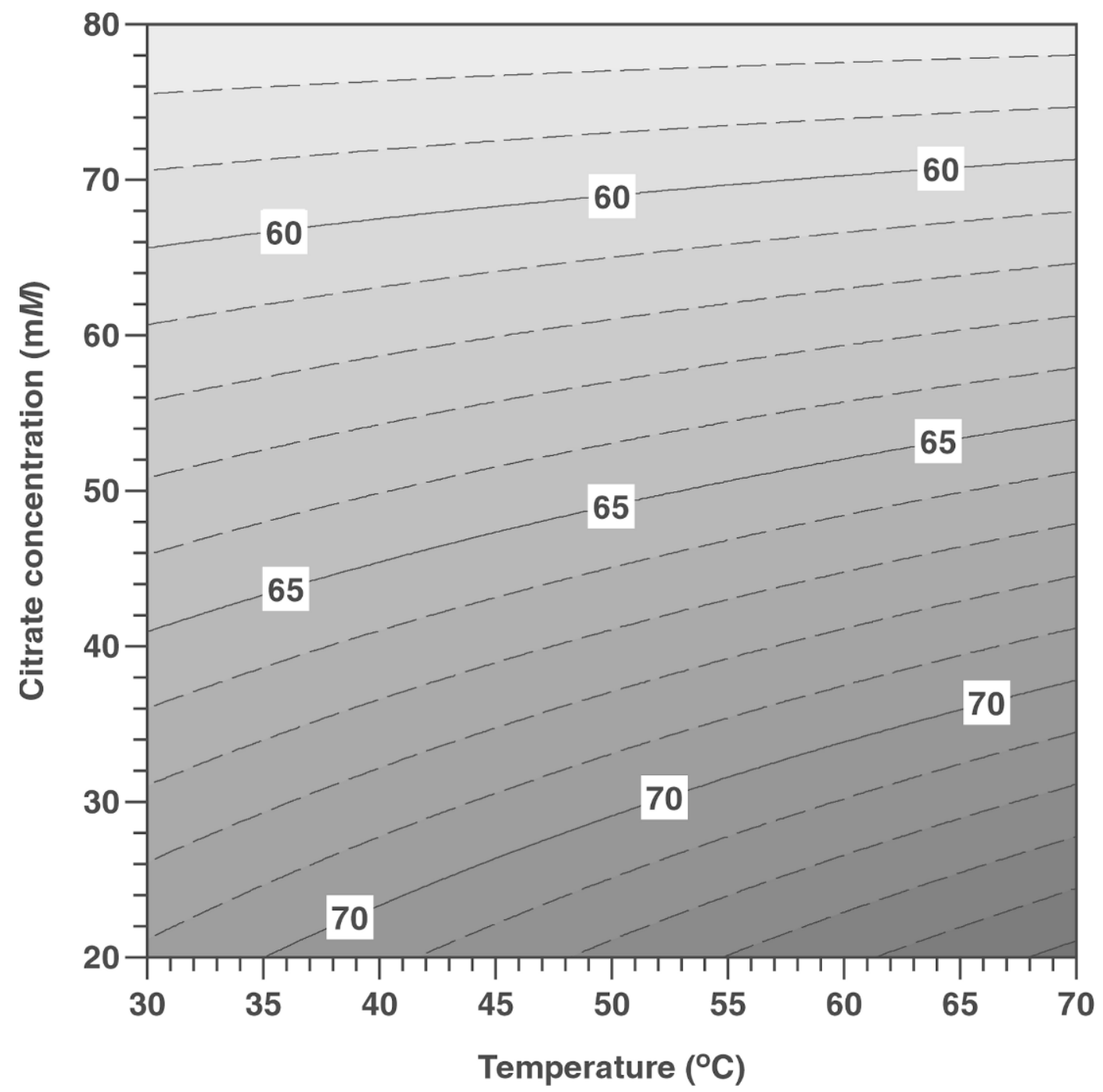

Figure 1. Contour plot of the $\mathrm{L}^{*}$ value (a measure of casein micelle dissociation) of butter serum as a function of temperature and citrate concentration. The original $\mathrm{L}^{*}$ value was 77.4 at $20^{\circ} \mathrm{C}$. 


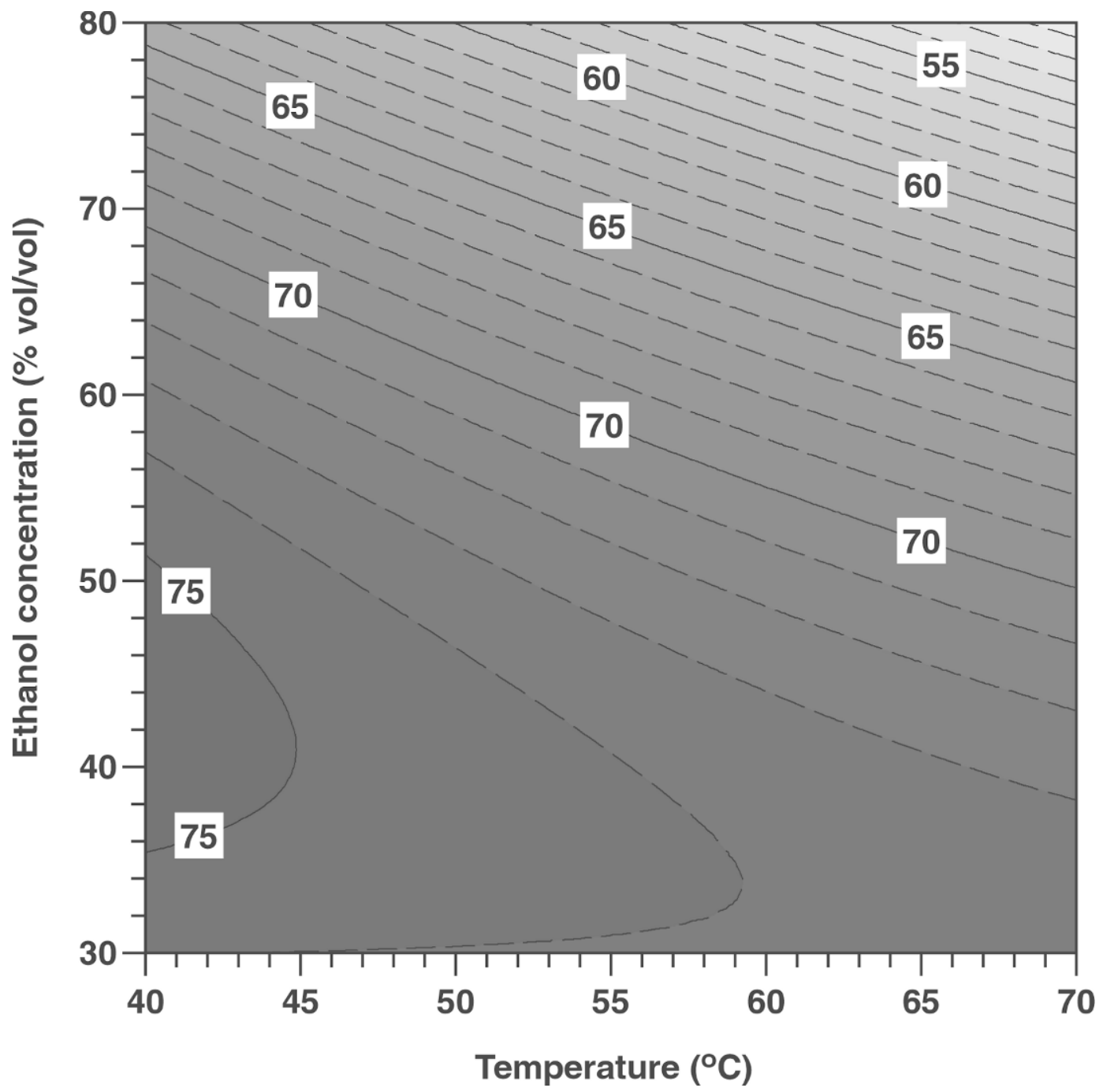

Figure 2. Contour plot of the $\mathrm{L}^{*}$ value (a measure of casein micelle dissociation) of butter serum as a function of temperature and alcohol concentration. Note that the latter is the concentration of ethanol in the water solution, which is mixed with the butter serum in a $1: 1$ ratio. The original $\mathrm{L}^{*}$ value of a 1:1 water:butter serum mixture was 74.7 at $20^{\circ} \mathrm{C}$.

icity and a reduction of phosphoseryl-mediated crosslinking (O’Connell et al., 2001b).

\section{Microfiltration Experiments}

Processing. Cellulose acetate membranes with a pore diameter of $0.15 \mu \mathrm{m}$ were used for all experiments. According to the manufacturer, these membranes exert a low protein binding capacity, are hydrophilic, and are suitable for alcoholic and aqueous media at elevated temperatures. However, at the startup of MF tests with butter serum at $50{ }^{\circ} \mathrm{C}$ and $80 \%$ ethanol, the filtration membrane was destroyed before optimal operation conditions were reached. This was observed twice more upon replacement of the membrane. Most likely, the chemical structure of the membrane was altered by the high ethanol concentration, resulting in a decrease of membrane rigidity. Therefore, microfiltration tests were only performed on butter serum in the presence of sodium citrate.

Because temperature had only a minor influence on casein micelle dissociation at high sodium citrate concentrations, the experiments were carried out at $50^{\circ} \mathrm{C}$ instead of the optimal $30^{\circ} \mathrm{C}$, which resulted in much higher permeate fluxes. Transmembrane pressure was $0.1 \mathrm{MPa}$ at a feed flux of $500 \mathrm{~L} / \mathrm{h}$, which results in a feed velocity of $2.14 \mathrm{~m} / \mathrm{s}$ over the membrane, ensuring a turbulent environment that minimizes fouling. Typical filtration curves for butter serum with and without sodium citrate $(80 \mathrm{mM})$ are given in Figure 3. Similar permeate fluxes were observed by Morin et al. (2004) upon the microfiltration of buttermilk. The presence of 


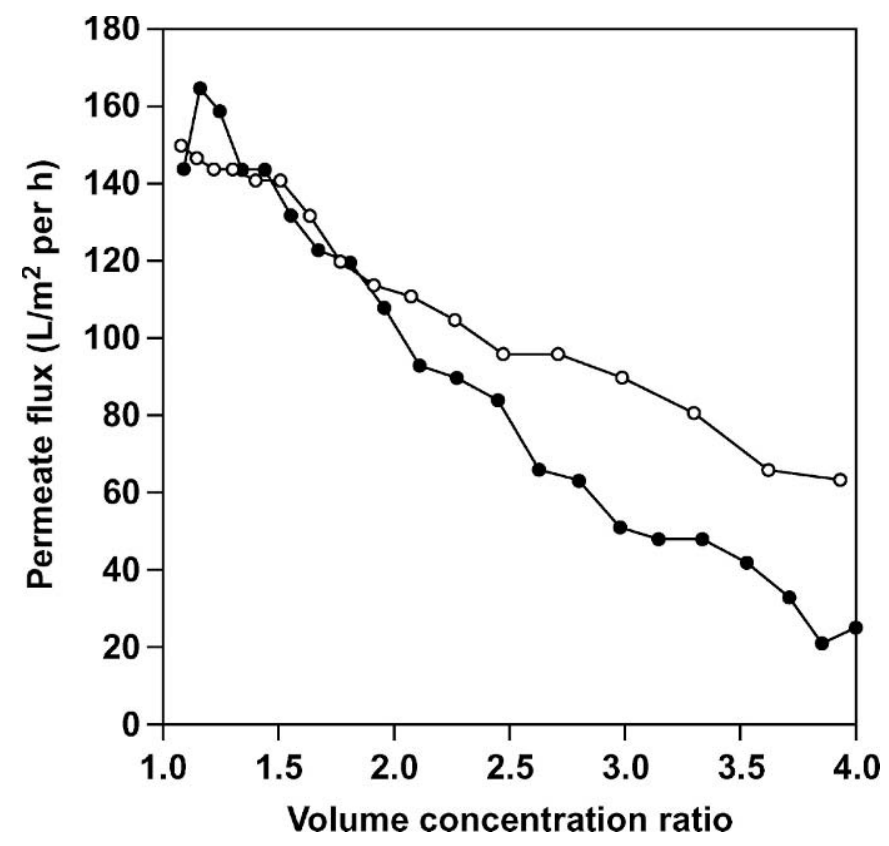

Figure 3. Permeate flux during microfiltration of reconstituted butter serum $(\bigcirc)$ and reconstituted butter serum in the presence of $80 \mathrm{mM}$ sodium citrate (). Temperature was kept at $50^{\circ} \mathrm{C}$, the transmembrane pressure at $0.1 \mathrm{MPa}$, and the feed velocity over the membrane at $2.14 \mathrm{~m} / \mathrm{s}$.

sodium citrate led to important changes in filtration characteristics, resulting in a higher permeate flux and a slower permeate flux decay, and consequently a shorter processing time. Fouling coefficients were in agreement with this observation. The $\mathrm{FC}$ varies between 0 (not fouled) and 1 (completely fouled). In combination with sodium citrate, the coefficient was found to be lower $(0.92 \pm 0.02)$ than without sodium citrate $(0.98 \pm 0.03)$, pointing out a lower fouling of the membrane in the presence of citrate. A higher DM content of the feed and more intense pore blocking by casein micelles in the case of native butter serum filtration are most likely the cause of the higher fouling rate. Comparison with other FC values reported in the literature is difficult due to different processing conditions. Rao (2002) observed much lower FC values (0.65 to 0.68) upon the ultrafiltration of buttermilk, but it is well known that UF membranes are less prone to fouling than MF membranes (Cheryan, 1998).

Composition of Butter Serum Fractions. The compositional data of all fractions are given in Table 3 . The gross composition of butter serum is comparable with buttermilk, except for neutral and polar lipids, which are higher. A PL HPLC profile of butter serum is given in Figure 4, in which complete separation of all PL classes can be observed. Separation was achieved in less than 19 min. Major PL were phosphatidylcholine
$(33.5 \pm 0.2 \mathrm{~g} / 100 \mathrm{~g}$ of PL), sphingomyelin $(27.9 \pm 1.8 \mathrm{~g} /$ $100 \mathrm{~g}$ of PL), and phosphatidylethanolamine $(18.7 \pm 2.0$ $\mathrm{g} / 100 \mathrm{~g}$ of PL). Minor PL were lactosylceramide (8.0 \pm $0.4 \mathrm{~g} / 100 \mathrm{~g}$ of PL), phosphatidylinositol $(6.3 \pm 0.7 \mathrm{~g} / 100$ $\mathrm{g}$ of PL), phosphatidylserine $(3.6 \pm 0.9 \mathrm{~g} / 100 \mathrm{~g}$ of PL), and glucosylceramide $(2.0 \pm 0.3 \mathrm{~g} / 100 \mathrm{~g}$ of PL). Total sphingolipid content (the sum of glucosylceramide, lactosylceramide, and sphingomyelin) accounted for 37.9 $\pm 1.9 \mathrm{~g} / 100 \mathrm{~g}$ of PL. Sodium dodecyl sulfate-PAGE revealed the presence of major amounts of MFGM proteins (Figure 5, lane 2). The presence of xanthin oxidase/ dehydrogenase, butyrophilin, adipophilin, periodic acid Schiff 6/7 (PAS 6/7), CD36, and mucin (MUC1) were affirmed by comparison with the MFGM protein standard. Construction of calibration curves, using reference proteins such as $\alpha$-LA, $\beta$-LG, BSA, and xanthin oxidase, revealed that the intensity of coloration with Coomassie Blue is highly dependent on the type of protein. Furthermore, it was found that saturation occurs at high concentrations, which could lead to an underestimation of the actual concentration of each individual protein. Because no commercial standards of separate MFGM proteins are available, no accurate quantification was possible. As such, these SDS-PAGE results should only be interpreted qualitatively.

In Table 4, retention coefficients and mass balances are given for both filtration experiments. As expected, lactose was only slightly retained by the membrane. No differences in retention between both experiments were observed for lipids, PL, and lactose. No significant differences in relative amounts of PL classes could be observed between the different filtration fractions. Sodium citrate had a major effect on protein transmission. In the presence of sodium citrate, the retention of proteins was almost halved, resulting in higher protein concentrations in the permeate. It can be clearly seen in Figure 5 that only whey proteins and traces of caseins are present in the native butter serum permeate (lane 6 ), whereas in the presence of sodium citrate (lane 7), caseins and MFGM proteins are present. Sodium citrate could have a similar effect on the MFGM particles as on casein micelles. It has been shown that the addition of Ca induces formation of large MFGM aggregates. This process has been used for the clarification of whey (Fauquant et al., 1985). Therefore, it is likely that depletion of the available Ca by citrate addition could induce an inverse effect and lead to smaller MFGM particles, which could partially pass the filtration membrane.

For native butter serum, the mass balance was less than $100 \%$ for proteins, but not for PL, whereas the reverse was true for butter serum with sodium citrate. In the case of PL, this discrepancy was also observed by other workers (Theodet and Gandemer, 1994; Rombaut et al., 2006) upon the filtration of whey PL. They 
Table 3. Composition of reconstituted butter serum $(4.5 \mathrm{~L})$, microfiltration retentates $(0.9 \mathrm{~L})$ and permeates $(3.4 \mathrm{~L})$ obtained with and without citrate addition ${ }^{1}$

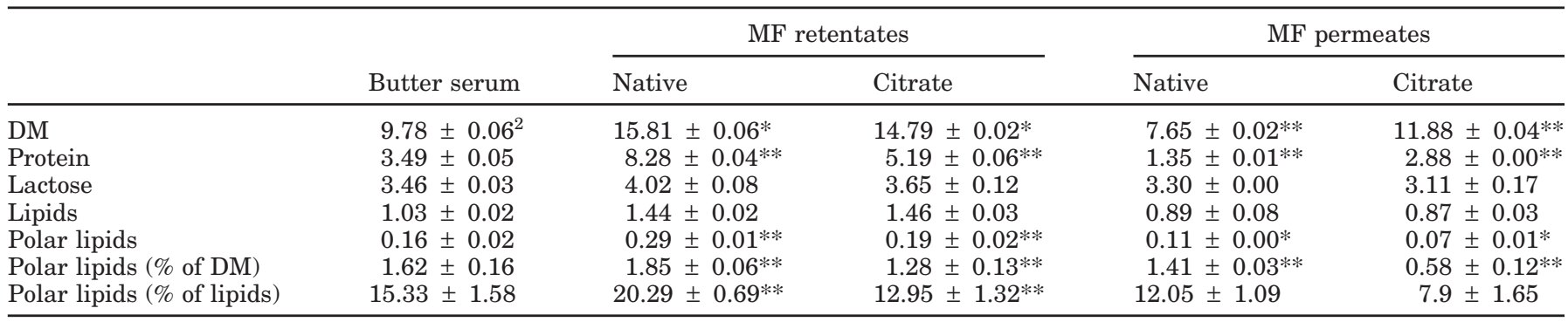

${ }^{1}$ Values are given in $\mathrm{g} / 100 \mathrm{~g}$ of product, unless stated otherwise. Subcolumn values in the same line with * and $* *$ differ significantly $(P$ $<0.05)$ and highly significantly $(P<0.01)$.

${ }^{2}$ Dry matter of butter serum was increased to $12.69 \pm 0.04$ after addition of sodium citrate $(80 \mathrm{~m} M)$.

concluded that a significant amount of PL (up to $32 \%$ of total whey PL) was part of the fouling layer, and remained on the membrane. Upon microfiltration of pure butter serum, the proteins appear to be the main cause of pore blocking and fouling, because protein recovery is only $87 \%$. Most likely, this is caused by the casein micelles. Their average diameter is around 120 $\mathrm{nm}$, which is comparable to that of the membrane's average pore diameter. After addition of sodium citrate, which causes a disruption of the casein micelles into smaller particles, the MFGM particles become the main factor of pore blocking and fouling, because the recovery of PL (and inherently, MFGM fragments) drops to $64 \%$. This is confirmed by the presence of MFGM proteins in the permeate (Figure 5, lane 7). Compared with the $\mathrm{PL}$, the recovery of lipids was much higher. The latter fraction mainly occurs as fat globules, which are 10 to

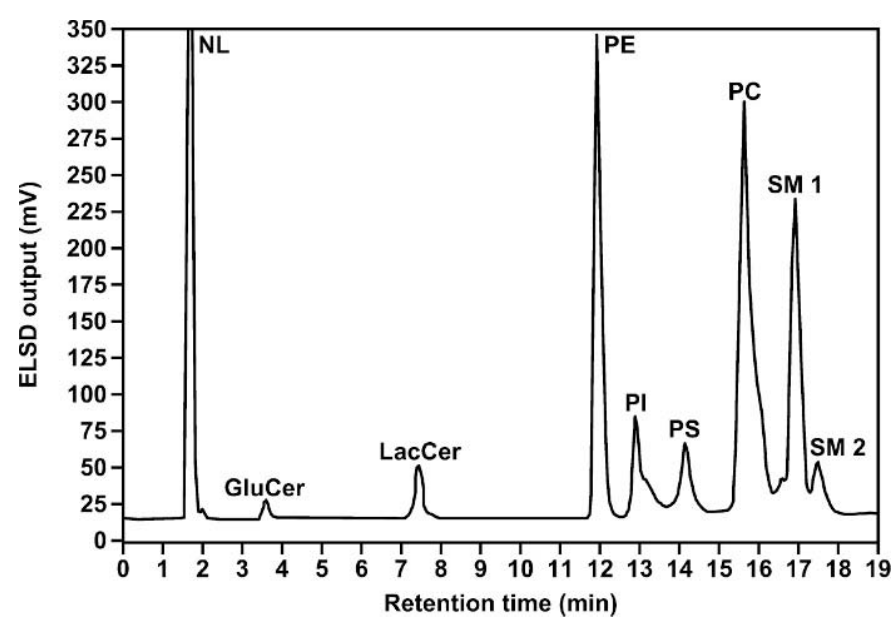

Figure 4. Polar lipid profile of butter serum as obtained by HPLCevaporative light-scattering detection (ELSD). NL = neutral lipids, GluCer $=$ glucosylceramide, LacCer $=$ lactosylceramide, $\mathrm{PE}=$ phosphatidylethanolamine, $\mathrm{PI}=$ phosphatidylinositol, $\mathrm{PS}$ = phosphatidylserine, $\mathrm{PC}=$ phosphatidylcholine, $\mathrm{SM}=$ sphingomyelin.
100 times larger than MFGM fragments. As such, these relatively large particles play only a small role in membrane fouling compared with MFGM particles and caseins. The lipid recovery values were also confirmed by the recovery of $\mathrm{DM}$, which was $99 \pm 1 \%$ in both filtration experiments.

Because of the differences in retention between PL and the other main constituents, PL concentration on a DM basis ( $\mathrm{g}$ of PL/100 $\mathrm{g}$ of DM) and on a lipid basis ( $g$ of PL/100 $g$ of lipid) was increased upon the filtration of pure butter serum. The combination with sodium citrate resulted in a lower DM content of the retentate, but this could not compensate the losses of PL on the membrane. As a result, the PL on a DM basis were even lower when sodium citrate was added.

\section{CONCLUSIONS}

Although butter serum is a fraction that contains high amounts of MFGM particles, the presence of caseins in the serum remains a problem for further purification by microfiltration. Upon direct filtration, the caseins are completely retained, and even upon further washing out of other constituents by diafiltration, they remain the main constituent of the DM fraction. As such, only moderate PL purity can be obtained. Addition of ethanol or citrate was found to be effective for the dissociation of casein micelles into smaller particles, which could then pass the filtration membrane. Filtration in the presence of ethanol requires the use of inert ceramic membranes and it is not clear if the use of ethanol would be economically feasible in a commercial environment. Upon addition of sodium citrate, caseins successfully passed the MF membrane, but a high fouling with PL was observed. Finally, further purification by membrane techniques implies the washing out of other constituents by means of diafiltration, which would result in high permeate losses; the retention in both experiments was only around $64 \%$. A reduction of 


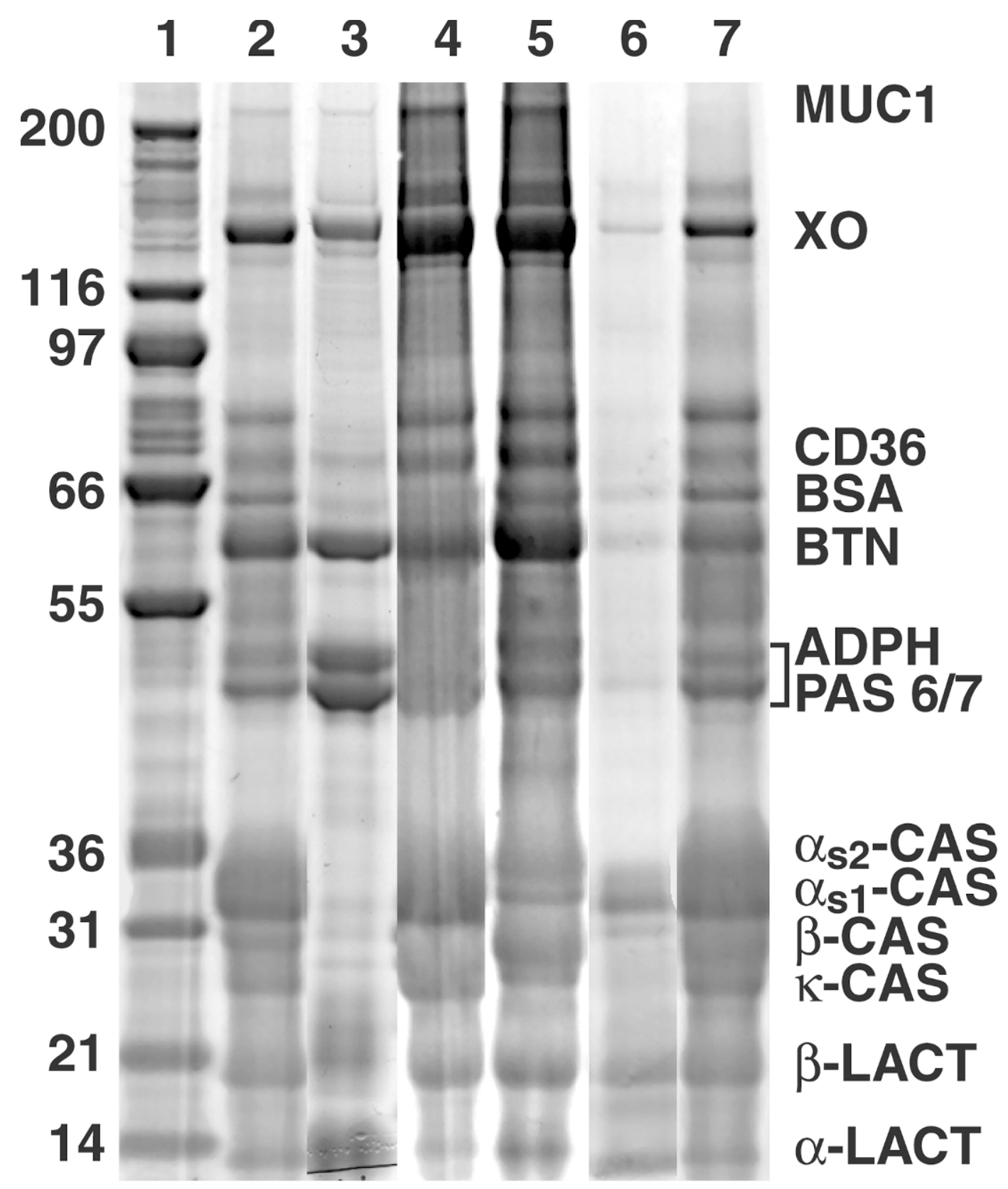

Figure 5. Sodium dodecyl sulfate-PAGE gel of the different fractions obtained from butter serum. Lane $1=$ molecular weight marker $(\mathrm{kDa})$; lane 2 = reconstituted butter serum; lane $3=$ milk fat globule membrane (MFGM) standard; lanes 4 and $5=$ microfiltration retentates of butter serum without and with citrate addition, respectively (vertical streaking in lane 4 is due to oversampling; as such, comparison with other lanes with respect to concentration should be done with some precaution); lanes 6 and $7=$ microfiltration permeates of butter serum without and with citrate addition, respectively. The naming of the major MFGM proteins has been done according to the review article of Mather (2000): ADPH = adipophilin; BTN = butyrophilin; CD36 = cluster of differentiation 36; MUC1 = mucin 1; PAS 6/7 = periodic acid Schiff 6/7; and XO = xanthin oxidase/dehydrogenase. Observed whey proteins are BSA, $\alpha$-LA, and $\beta$-LG. The 4 major caseins (CAS) were also detected.

membrane pore diameter would not be a solution either, because this would most likely result in higher retention of casein submicelle particles. As such, microfiltration, even with the aid of casein micelle dissociating agents, seems unsuitable for efficient purification of
MFGM material from butter serum. A possible alternative could be the complete coagulation of caseins by acid or rennet addition, thereby minimizing losses of MFGM material in the curd by adjusting the experimental conditions. After separation of the curd and butter serum 
Table 4. Retention coefficients and mass balance for the microfiltration of butter serum with and without citrate addition

\begin{tabular}{lll}
\hline & $\begin{array}{l}\text { Without } \\
\text { citrate }\end{array}$ & $\begin{array}{l}\text { With } \\
\text { citrate }\end{array}$ \\
\hline $\begin{array}{l}\text { Retention coefficient (\%) } \\
\text { Protein }\end{array}$ & $83.7 \pm 0.2$ & $44.5 \pm 0.7$ \\
Lactose & $18.1 \pm 1.6$ & $14.8 \pm 5.3$ \\
Lipids & $38.0 \pm 5.5$ & $40.5 \pm 2.2$ \\
Polar lipids & $63.2 \pm 1.4$ & $63.7 \pm 8.3$ \\
Mass balance (\%) & $87 \pm 1$ & $99 \pm 1$ \\
Protein & $100 \pm 1$ & $94 \pm 6$ \\
Lactose & $100 \pm 6$ & $98 \pm 4$ \\
Lipids & $97 \pm 10$ & $64 \pm 8$ \\
Polar lipids & & \\
\hline
\end{tabular}

whey, the latter (rich in MFGM particles) could be further purified by coagulation or ultrafiltration or microfiltration techniques.

\section{ACKNOWLEDGMENTS}

B. Lewille and M. Jooris are acknowledged for their technical assistance. Spectral Services (Köln, Germany) is acknowledged for providing a milk polar lipid standard.

\section{REFERENCES}

Acker, L. 1967. Analytik der Lebensmittel. Nachweis and Bestimmung der Mono- and oligosacchariden. Pages 383-401 in Handbuch der Lebensmittel chemie. W. Diemar, ed. Springer-Verlag, Berlin, Germany.

Ardisson-Korat, A. V., and S. S. H. Rizvi. 2004. Vatless manufacturing of low-moisture part-skim Mozzarella cheese from highly concentrated skim milk microfiltration retentates. J. Dairy Sci. 87:3601-3613.

Cano-Ruiz, M. E., and R. L. Richter. 1997. Effect of homogenization pressure on the milk fat globule membrane proteins. J. Dairy Sci. 80:2732-2739.

Cheryan, M. 1998. Ultrafiltration and Microfiltration Handbook. 2nd ed. CRC Press LLC, Boca Raton, FL.

Christie, W. W., R. C. Noble, and G. Davies. 1987. Phospholipids in milk and dairy-products. J. Soc. Dairy Technol. 40:10-12.

Corredig, M., and D. G. Dalgleish. 1997. Isolates from industrial buttermilk: Emulsifying properties of materials derived from the milk fat globule membrane. J. Agric. Food Chem. 45:4595-4600.

Corredig, M., R. R. Roesch, and D. G. Dalgleish. 2003. Production of a novel ingredient from buttermilk. J. Dairy Sci. 86:2744-2750.

Danthine, S., C. Blecker, M. Paquot, N. Innocente, and C. Deroanne. 2000. Progress in milk fat globule membrane research: A review. Lait 80:209-222.

Deeth, H. C. 1997. The role of phospholipids in the stability of milk fat globules. Aust. J. Dairy Technol. 52:44-46.

Duan, R. D. 2005. Anticancer compounds and sphingolipid metabolism in the colon. In Vivo 19:293-300.

Eckhardt, E. R. M., D. Q. H. Wang, J. M. Donovan, and M. C. Carey. 2002. Dietary sphingomyelin suppresses intestinal cholesterol absorption by decreasing thermodynamic activity of cholesterol monomers. Gastroenterology 122:948-956.

Evers, J. M. 2004. The milkfat globule membrane - Compositional and structural changes post secretion by the mammary secretory cell. Int. Dairy J. 14:661-674.

Fauquant, J., E. Vieco, G. Brule, and J. L. Maubois. 1985. Clarification of sweet cheese whey by thermocalcic aggregation of residual fat. Lait 65:1-20.
Fox, P. F., and P. L. H. McSweeney. 1998. Dairy Chemistry and Biochemistry. Blackie Academic \& Professional, London, UK.

Goudédranche, H., J. Fauquant, and J. L. Maubois. 2000. Fractionation of globular milk fat by membrane microfiltration. Lait 80:93-98.

Huppertz, T., P. F. Fox, and A. L. Kelly. 2004. Properties of casein micelles in high pressure-treated bovine milk. Food Chem. 87:103-110.

IDF. 1993. Milk. Determination of Nitrogen Content. IDF Standard 20B. Int. Dairy Fed., Brussels, Belgium.

IDF. 1987a. Milk. Total solids in milk - Gravimetric method. IDF Standard 21B. Int. Dairy Fed., Brussels, Belgium.

IDF. 1987b. Buttermilk. Determination of Fat Content: Röse-Gottlieb-Gravimetric method. IDF Standard 22B. Int. Dairy Fed., Brussels, Belgium.

Kanno, C. 1989. Emulsifying properties of bovine milk fat globule membrane in milk fat emulsion - Conditions for the reconstitution of milk-fat globules. J. Food Sci. 54:1534-1539.

Kanno, C., Y. Shimomura, and E. Takano. 1991. Physicochemical properties of milk fat emulsions stabilized with bovine milk fat globule membrane. J. Food Sci. 56:1219-1223.

Keenan, T. W., I. H. Mather, and D. P. Dylewski. 1999. Physical equilibria: Lipid phase. Pages 511-583 in Fundamentals of Dairy Chemistry. 3d ed. N. P. Wong, ed. Aspen Publishers, Inc. Gaithersburg, MD.

Kim, H. H. Y., and R. Jimenez-Flores. 1995. Heat-induced interactions between the proteins of milk fat globule membrane and skim milk. J. Dairy Sci. 78:24-35.

Mather, I. H. 2000. A review and proposed nomenclature for major proteins of the milk-fat globule membrane. J. Dairy Sci. 83:203-247.

McGann, T. C. A., and P. F. Fox. 1974. Physicochemical properties of casein micelles reformed from urea-treated milk. J. Dairy Res. 41:45-53.

McPherson, A. V., and B. J. Kitchen. 1981. The proteins and lipids of the aqueous phase of butter. Aust. J. Dairy Technol. 36:17-20.

Morin, P., R. Jimenez-Flores, and Y. Pouliot. 2004. Effect of temperature and pore size on the fractionation of fresh and reconstituted buttermilk by microfiltration. J. Dairy Sci. 87:267-273.

Noh, S. K., and S. I. Koo. 2004. Milk sphingomyelin is more effective than egg sphingomyelin in inhibiting intestinal absorption of cholesterol and fat in rats. J. Nutr. 134:2611-2616.

O'Connell, J. E., A. L. Kelly, M. A. E. Auty, P. F. Fox, and K. G. de Kruif. 2001a. Ethanol-dependent heat-induced dissociation of casein micelles. J. Agric. Food Chem. 49:4420-4423.

O'Connell, J. E., A. L. Kelly, P. F. Fox, and K. G. de Kruif. 2001b. Mechanism for the ethanol-dependent heat-induced dissociation of casein micelles. J. Agric. Food Chem. 49:4424-4428.

Pfeuffer, M., and J. Schrezenmeir. 2001. Dietary sphingolipids: Metabolism and potential health implications. Kieler Milchw. Forsch. 53:31-42.

Rao, H. G. R. 2002. Mechanisms of flux decline during ultrafiltration of dairy products and influence of $\mathrm{pH}$ on flux rates of whey and buttermilk. Desalination 144:319-324.

Rombaut, R., J. Van Camp, and K. Dewettinck. 2005. Analysis of phospho- and sphingolipids in dairy products by a new HPLC method. J. Dairy Sci. 88:482-488.

Rombaut, R., J. Van Camp, and K. Dewettinck. Phospho- and sphingolipid distribution during processing of milk, butter and whey. Int. J. Food Sci. Technol. 41:435-443.

Sachdeva, S., and W. Buchheim. 1997. Recovery of phospholipids from buttermilk using membrane processing. Kieler Milchw. Forsch. 49:47-68.

Schmelz, E. M. 2004. Sphingolipids in the chemoprevention of colon cancer. Front. Biosci. 9:2632-2639.

Schneider, M. 2001. Phospholipids for functional food. Eur. J. Lipid Sci. Technol. 103:98-101.

Spitsberg, V. L. 2005. Bovine milk fat globule membrane as a potential nutraceutical. J. Dairy Sci. 88:2289-2294.

Theodet, C., and G. Gandemer. 1994. Fate of lipids during whey defatting process. Lait 74:281-295. 
Trouve, E., J. L. Maubois, M. Piot, M. N. Madec, J. Fauquant, A. Rouault, J. Tabard, and G. Brinkman. 1991. Retention of various microbial species during milk epuration by cross-flow microfiltration. Lait 71:1-13.

Udabage, P., I. R. McKinnon, and M. A. Augustin. 2000. Mineral and casein equilibria in milk: Effects of added salts and calciumchelating agents. J. Dairy Res. 67:361-370.
Vesper, H., E. M. Schmelz, M. N. Nikolova-Karakashian, D. L. Dillehay, D. V. Lynch, and A. H. Merrill. 1999. Sphingolipids in food and the emerging importance of sphingolipids to nutrition. J. Nutr. 129:1239-1250.

Zadow, J. G. 1993. Alcohol-mediated temperature-induced reversible dissociation of the casein micelle in milk. Aust. J. Dairy Technol. 48:78-81. 